\title{
Female Genital Mutilation: Potential for HIV Transmission in sub-Saharan Africa and Prospect for Epidemiologic Investigation and Intervention
}

\author{
Emmanuel Monjok, $M D, M P H^{1,}$ E.James Essien, $M D, D r P H^{1,2}$, Laurens Holmes, Jr, MD,DrPH ${ }^{1,2}$
}

\begin{abstract}
Female Genital Mutilation (FGM) which involves alteration of the female genitalia for non-medical grounds is prevalent in Sub-Saharan Africa, associated with long- term genitourinary complications, and possible HIV transmission. This minireview aims to examine FGM and the possibility of HIV transmission through this procedure. We performed an electronic search using Medline for articles published between 1966 to 2006 for evidence of FGM practice, its complications, and the nexus between this procedure and HIV sero-positivity. The results indicate ongoing FGM practice, albeit prevalence reduction, due probably to the increasing knowledge of the consequences of FGM as a result of non-sterile techniques. Secondly, the complications of FGM are well established which include Genitourinary disorders. Further, while data is limited on HIV transmission via FGM, there is biologic plausibility in suggesting that FGM may be associated with increasing prevalence of HIV in sub-Saharan Africa. This paper recommends further studies in order to assess the association between FGM and HIV transmission. (Rev Afr Santé Reprod 2007; 11[1]:33-42)
\end{abstract}

\section{RÉSUMÉ}

Mutilation génitale féminine: Potentiel pour la transmission du VIH en Afrique subsaharienne et la perspective pour l'enquête et l'intervention épidémiologiques La mutilation génitale féminine (MGF) qui implique la modification des organes génitaux féminins pour des raisons non médicales est répandue en Afrique subsaharienne et elle est liée aux complications génitaux-urinaires à long terme et peut-être à la transmission du VIH. Cette mini-étude a pour objectif d'examiner la MGF et la possilibité de la transmission du VIH par cette procédure. Nous avons recherché sur l'internet à l'aide de la medline des articles publiés entre 1966 et 2006 pour l'évidence de la pratique de la MGF, ses complications et la liaison entre cette procedure et la séropositivité du VIH. Les résultats montrent que la pratique de la MGFse poursuit bien que la prévalence soit réduite dû probablement à la croissance de la connaissance des conséquences de la MGF à cause des conséquences non-stériles. Deuxièment, les complications de la MGF sont bien établies y compris les troubles génitaux-urinaires. De plus, alors que les données sont limitées par rapport à la transmission du VIH par la MGF, il y a une plausibilité biologique de suggérer que la MGF peut être liée à la prévalence croissante du VIH en Afrique subsaharienne. L'article préconise encore d'études pour permettre d'évaluer le lien entre la MGF et la transmission du VIH. (Rev Afr Santé Reprod 2007; 11[1]:33-42)

KEY Words: Female genital mutilation, HIV transmission, sub-Saharan Africa, HIV riskefactors

${ }^{1}$ Institute of Community Health, University of Houston, Texas Medical center, Houston, TX 77030, US A,

${ }^{2}$ University of Texas School of Public Health, Houston TX, 77030, USA.

Corresponding author: Laurens Holmes Jr., Institute of Community Health, University of Houston, Texas Medical Center, 1441 Moursund Street, Room 116, Houston TX 77030, USA. E-mail: Iholmes3@uh.edu Fax: ( 713) 795 8383 Tel: (713) 7958351 


\section{Introduction}

Female Genital Mutilation (FGM) is a term used to describe traditional practices that involve the cutting of female genitalia. Other commonly used terms for this procedure are female circumcision, female genital cutting or female genital surgeries. FGM persist in sub-Saharan Africa with the practice still associated with non-sterile techniques and multiple complications, including though not limited to, hematological, urologic, hemodynamic, infections and psychosocial morbidities. Further, there is a possibility that this practice may be associated with increased transmission of HIV infection in sub-Saharan populations.

There are multiple and diversified connotations of FGM. The World Health Organization (WHO) describes FGM as the intentional removal of part or all of the external genitalia, or other damages to the female genitalia for cultural or other non-therapeutic purposes. ${ }^{1}$ In sub-Saharan Africa this practice involves use of shared and crude instruments; thus the sharing of blood. ${ }^{2}$ The genital trauma caused by FGM and the consequences, according to the $\mathrm{WHO},{ }^{3}$ may increase the susceptibility to HIV infection. Secondly, herbs and foreign bodies inserted into the vagina by traditional methods may increase the possibility of HIV transmission, due to inflammation and abrasions to the vaginal epithelium.

Female genital mutilation is practiced in 28 countries of sub-Saharan Africa; a few countries in the Middle East and Asia, and among immigrant populations from these countries in Europe, North America and Australasia. It has been estimated that there are over 120 million girls and women worldwide that have undergone this procedure, and at least 2 million girls are at risk of being genitally mutilated each year, at about 6000 girls per day. ${ }^{4-6}$ Eighteen African countries have prevalence rates of $50 \%$ or higher. The highest prevalence is in Somalia and Djibouti $(98 \%)$, but these estimates vary from country to country and within various ethnic groups. ${ }^{1}$
In spite of the known complications and the potential for HIV transmission through FGM, there are very limited studies reviewing this practice currently and presenting perspective on the probability of FGM leading to HIV transmission. Biologically, any sexually-related viral or bacterial pathogen has increased propensity for transmission, given trauma or pre-existing laceration to the vaginal epithelium. FGM increases the risk of vaginal epithelial damage and consequently increase the probability of HIV transmission.

This mini-review paper aimed to explore the historical perspective of FGM, delving into its description, patterns of practice, and the possibility or likelihood of FGM as a non-sterile technique of mutilation, resulting in HIV transmission. This paper, if anything, may provoke thought process on the probability of increased HIV transmission, given FGM, thus encouraging hypothesis generation and testing on the association between FGM and HIV transmission.

\section{MATERIALS AND METHODS}

Electronic search of published literature was conducted using Medline with the key words: female genital mutilation, female genital cutting, female circumcision, and health complications as well as female genital mutilation, female genital cutting, female circumcision and HIV. The search was restricted to English language articles only. We searched all original articles that were published between 1966 to 2006 on FGM ( $k=789)$. The search for the later resulted in the selection of five (5) eligible articles $(25-27,29,30)$ whereas the former resulted in seven (7) eligible articles (10,1518, 21-23). As part of the exclusion criteria, we included only the most comprehensive articles from author/s if two (2) or more articles were published on the same study population in different years. Also, we excluded articles that provided abstracts only. Apart from the historical perspective, only original articles that addressed FGM in subSaharan Africa were included in this study.

African Journal of Reproductive Health Vol. 11 No.1 April 2007 
QUALITATIVE SYNTHESES (RESULTS)

\section{Notion and Classification of FGM}

Female Genital Mutilation has been in practice for some 4000 years and continues to be prevalent in most parts of the world, especially in subSaharan Africa (Table 1). FGM typically involves the alteration of the female genitalia using a traditional pattern of resection that is characterized by non-sterile technique.
The World Health Organization (WHO) has classified FGM into four types, ${ }^{7}$ in order to strengthen policy formulation including legislation, research and training. According to WHO classification matrix, FGM taxonomy includes: Type I - the partial or total removal of the clitoris, Type II - partial or total removal of the clitoris together with partial or total excision of the labia minora, Type III - partial or total removal of the external genitalia and stitching or narrowing of the vaginal orifice and Type $1 \mathrm{~V}$ -

Table 1. Historical Perspective of Female Genital Multilation

\begin{tabular}{|c|c|c|c|c|}
\hline Place & Time & Traditional Indications & Practice & Comments \\
\hline Greece & $163 \mathrm{BC}$ & $\begin{array}{l}\text { Done as a substitute for human } \\
\text { sacrifice }\end{array}$ & $\begin{array}{l}\text { Simple excision } \\
\text { of clitoris }\end{array}$ & $\begin{array}{l}\text { It was regarded as a } \\
\text { ritual }\end{array}$ \\
\hline Russia & $?$ & $\begin{array}{l}\text { To ensure a state of perpetual } \\
\text { virginity in the communities }\end{array}$ & $\begin{array}{l}\text { Simple excision } \\
\text { of clitoris }\end{array}$ & \\
\hline$\overline{\text { Egypt }}$ & $\begin{array}{l}\text { First reported about } \\
4000 \text { years ago }\end{array}$ & Cultural and tradition & $\begin{array}{l}\text { Clitoridectomy, } \\
\text { excision and } \\
\text { infibulation } \\
\text { (pharaonic } \\
\text { circumcision) }\end{array}$ & $\begin{array}{l}\text { Some people argue } \\
\text { that it was due to the } \\
\text { religion of Islam, } \\
\text { but this procedure } \\
\text { is not practices in } \\
\text { all Muslims countries. }\end{array}$ \\
\hline $\begin{array}{l}\text { Sudan/ } \\
\text { Eritrea/ } \\
\text { Djibouti }\end{array}$ & $\begin{array}{l}\text { Still persis till date, } \\
\text { with high prevlence } \\
\text { rates up to } 95 \%\end{array}$ & $\begin{array}{l}\text { Mothers carry out FGM as a } \\
\text { means of securing their } \\
\text { daughters economic and } \\
\text { social future }\end{array}$ & $\begin{array}{l}\text { Clitoridectomy, } \\
\text { excision and } \\
\text { infibulation } \\
\text { (pharaonic } \\
\text { circumcision) }\end{array}$ & $\begin{array}{l}\text { This is a deep rooted } \\
\text { cultural practice and } \\
\text { it is not based on } \\
\text { Islam. }\end{array}$ \\
\hline Nigeria & $\begin{array}{l}\text { Still occur till date } \\
\text { in many communities } \\
\text { with prevalence rate } \\
\text { ranging from } \\
60 \%-90 \%\end{array}$ & $\begin{array}{l}\text { Cultural to reduce female sexual } \\
\text { desire or in some communities } \\
\text { a false myth that the clitoris will } \\
\text { grow and dangle like the male } \\
\text { penis or that during delivery if } \\
\text { the baby's head touches the } \\
\text { clitoris it will lead to death of } \\
\text { the new born. }\end{array}$ & $\begin{array}{l}\text { Clitoridectomy, } \\
\text { excision and } \\
\text { infibulation } \\
\text { (pharaonic circum- } \\
\text { cision). Infibula- } \\
\text { tion is not very } \\
\text { common in Nigeria } \\
\text { and mostly occur } \\
\text { in Northern Nigeria. }\end{array}$ & $\begin{array}{l}\text { Traditional and cultu- } \\
\text { ral practices with no } \\
\text { religious indication }\end{array}$ \\
\hline $\begin{array}{l}\text { Guinea/ } \\
\text { Burkina } \\
\text { Faso }\end{array}$ & $\begin{array}{l}\text { Still occur till date } \\
\text { in many communities } \\
\text { with prevalence rate } \\
\text { ranging from } \\
60 \%-90 \%\end{array}$ & $\begin{array}{l}\text { Cultural to reduce female sexual } \\
\text { desire or in some communities } \\
\text { a false myth that the clitoris } \\
\text { will grow and dangle like the } \\
\text { male penis ot that during } \\
\text { delivery if the baby's head } \\
\text { touches the clitoris it will lead } \\
\text { to death of the new born. }\end{array}$ & $\begin{array}{l}\text { Clitoridectory, exci- } \\
\text { sion and infibula- } \\
\text { tion (pharaonic } \\
\text { circumcision). }\end{array}$ & $\begin{array}{l}\text { Traditional and cultu- } \\
\text { ral practices with no } \\
\text { religious indication }\end{array}$ \\
\hline
\end{tabular}

African Journal of Reproductive Health Vol. 11 No.1 April, 2007 
traditional genital surgeries such as pricking or stretching the clitoris and/or surrounding tissues, cauterization by burning of the clitoris and surrounding tissues, introcision, scraping of the vaginal orifice, cuts into the vagina and introduction of substances into the vagina with the aim of tightening or narrowing the vagina. Whereas, there are other taxonomies of FGM, which are not delved into in this paper due to complexities, type III (sometimes known as Pharaonic circumcision or infibulation) is the most severe and accounts for $15 \%$ of all genital cuttings, ${ }^{7}$ while $85 \%$ of the cuttings are type I and II, ${ }^{7}$ and type II being the commonest. With respect to geographic locale, Type III operations occur predominantly in Somalia, northern Sudan and Djibouti, although it has been reported in parts of Ethiopia, Eritrea, northern Kenya, Mali and northern Nigeria.

\section{Practice and Resection techniques}

Female Genital Mutilation which is still practiced in sub-Saharan Africa and elsewhere in the world has been explicitly and unequivocally condemned by the WHO as an unacceptable medical practice and as such should not be practiced by health professionals in any setting. ${ }^{8}$ The WHO study group on FGM and obstetric outcome results indicated that women with FGM are significantly more likely than those without FGM to develop unwanted obstetric outcomes, with the risk of adverse events greater with type 111 FGM.' Further, the International Federation of Gynecology and Obstetric (FIGO) supports the WHO stance on medicalization of FGM. ${ }^{10}$

Female Genital Mutilation, to our knowledge is not a standard surgical procedure in western Medicine, with the practitioners of this "surgical procedure" commonly identified as perpetrators. FGM is usually carried out by traditional practitioners or lay persons, usually older women, using crude instruments and without any anesthesia. The crude instruments range from a scalpel to a piece of glass and are conducted in unhygienic and unsterile conditions. ${ }^{11}$ In spite of the non-involvement of western medical practitioners, historically trained medical personnel including doctors and nurses occasionally connive at and encourage FGM. Further, it has been suggested that about $12 \%$ of FGMs are carried out by physicians. ${ }^{12}$ The age at which FGM is practiced varies by locale. Amongst the nomads of Sudan it is performed at a few days old, while in Egypt and in countries of East Africa and the Horn of Africa, it is performed at about the age of 7 years. In addition, in some communities, FGM is performed in adolescence while other communities prefer to carry out the procedure shortly before marriage, e.g. the Ibo tribe in Nigeria. ${ }^{13}$

\section{Rationale for practice}

A variety of reasons (sociocultural, religious, psychosexual, hygienic and esthetic) have been suggested for the continuation of FGM in the locale where this procedure persist. These reasons include marriageability, curbing sexual desire, protecting virginity, religious rite, initiation to womanhood, improved hygiene, and beautification. ${ }^{14}$ In some communities in Eastern Nigeria, it is believed that if the head of the neonate touches the clitoris during child birth, the neonate will not survive. ${ }^{13}$

Further and of health significance, FGM has a deep-rooted cultural importance that some communities have allowed the medicalization of the procedure to minimize the health consequences associated with the traditional procedure. ${ }^{10,15}$ Regardless of this rationale, the WHO very firmly disapproves this procedure because it tends to perpetuate and promote FGM rather than to prevent or reduce its practice. ${ }^{10}$.

\section{Health and social Complications}

Female Genital Mutilation has been observed to decrease in prevalence in a number of countries despite no well defined interventions to reduce

African Journal of Reproductive Health Vol. 11 No.1 April 2007 
or eliminate this practice, ${ }^{15}$ due probably to the numerous complications and the potentials for viral infections, namely HIV. The complications of FGM are immediate and long-term, including medical, psychosexual and psychosocial. Severe gynecological and obstetrics complications, of FGM especially with the Type III or Infibulation have been observed., ${ }^{9,16-18}$ Table $2 \mathrm{a}$ and $2 \mathrm{~b}$ demonstrate acute and chronic complications of FGM respectively. ${ }^{19}$ FGM has been associated with psychological trauma including post traumatic stress and chronic behavioral ailments such as generalized anxiety, unipolar affective disorder, chronic irritability, frigidity and marital conflicts. ${ }^{20}$ Specific health and social complications of FGM has been observed to vary with the type of FGM. Circumcised women have been noted to have higher risk of tearing and still births compared with uncircumcised. ${ }^{21,22}$ A study of
1836 cohort of healthy premenopausal Nigerian women found a statistically significant increase in lower abdominal pain, malodorous vaginal discharge and genital ulcers among those with FGM compared to those without. ${ }^{23}$

\section{FGM and Association with HIV Transmission}

HIV/AIDS epidemic

The latest AIDS epidemic update in sub-Saharan Africa shows that about 2.58 million people are living with HIV, which represent $64 \%$ of the world's HIV cases with 3.2 million new cases and 2.4 million deaths. ${ }^{24} \mathrm{It}$ is therefore obvious that more than $60 \%$ of all people with HIV live in sub-Saharan Africa. ${ }^{24}$ There is little evidence of a declining epidemic in this region despite decline in HIV prevalence in many other countries.

\section{Table 2 (a). Immediate complications of Female Genital Mutilation}

\begin{tabular}{ll}
\hline Complications & Outcomes and illustrations \\
\hline A Bleeding & Hemorrhage - hemorrhage occurring as a result of torn blood vessels in \\
& the vaginal wall. \\
& $*$ Anemia - consequences of hemorrhage \\
& $*$ Hypotension - outcome effect due to continuous hemorrhage \\
& $*$ Oliguria - outcome effect due to hypovolemia \\
& $*$ shock - severe hypovolemia leading to shock \\
& $*$ death - outcome of severe of hemorrhage and hypovolemia \\
& $*$ cellulites - bacterial infection of subcutaneous tissues \\
& $*$ Abscess - pus formation \\
& $*$ pelvic inflammatory disease - widespread infection involving the female \\
& reproductive system \\
& $*$ Tetanus - infection with clostridium welchi, anerobic infection \\
& $*$ Gangrene - dead necrotic tissue from severe infection compromising the \\
& blood supply. \\
& $*$ Septic shock - severe septicemia leading to shock \\
& $*$ HIV infection - possible transmission of retroviruses \\
& $*$ urethral injuries - direct damage to urethra \\
& $*$ edema of the urethra consequences of urethral injury. \\
& $*$ oliguria - outcome effect of urethral damage \\
& $*$ Clavicle \\
& $*$ Femur \\
& $*$ Humerus \\
\hline C. Genital injury &
\end{tabular}

African Journal of Reproductive Health Vol. 11 No.1 April, 2007 
Table 2 (b). Long term complications of Female Genital Mutilation

\begin{tabular}{ll}
\hline Complications & Outcomes and illustrations \\
\hline A Urinary & $*$ urethral stricture. \\
& $*$ Meatal obstruction and stenosis \\
& $*$ Chronic urinary tract infection \\
& $*$ Urinary stones \\
& $*$ Meatitis \\
& $*$ Fibrosis \\
& $*$ Keloids formation \\
& $*$ partial and complete fusion of labia \\
& $*$ Hematocolpos \\
& $*$ Inclusions and sebaceous cysts \\
& $*$ Vulvar abscesses. \\
& $*$ Neuroma \\
& $*$ Chronic vaginal infection \\
& $*$ Dyspareunia \\
& $*$ Vaginismus \\
& $*$ Dysmenorrhea \\
& $*$ Menorrhagia \\
& $*$ Vaginal stenosis \\
& $*$ Infibulated scar \\
& $*$ Dyspareunia \\
& $*$ Apareunia \\
\hline Dain &
\end{tabular}

Prevalence levels remain "exceptionally" high and might not have reached their peak in several countries. Women are disproportionately affected by HIV and most still remain poorly informed.

\section{HIV modes of transmission}

The various modes of transmission of HIV and their possible association or enhancement through FGM procedure is shown in Table 3. These modes include sexual intercourse, which may be vaginal/penile, anal/penile, or oral sex, injection drug use and the sharing of needles and the exchange of blood products during non-sterile female genital mutilation. Unscreened blood transfusions still occur in some rural hospitals in sub-Saharan Africa, with its dangers of transmission of HIV and Hepatitis.

\section{HIV transmission and FGM}

HIV transmission from this FGM practice is enhanced through shared instruments and blood products during the practice of genital cutting as well as damage to the vaginal epithelium associated with the trauma, inflammation and complications. Other modes of HIV transmission, as well as other HIV risk factors may occur in association with this practice, making it difficult to ascertain whether FGM is the sole predisposing risk factor, as well as a contributing variable to the cumulative incidence of HIV in sub-Saharan Africa. Similarly, if approximately 6000 young girls undergo FGM daily and about 2 million young girls are at risk of being genitally mutilated in a year, the odds of FGM as a risk factor to HIV transmission remains to be assessed.

African Journal of Reproductive Health Vol. 11 No.1 April 2007 
Female Genital Mutilation: Potential for HIV Transmission in sub-Saharan Africa and Prospect for Epidemiologic . .

Table 3. Modes of HIV transmission and possible relationship with Female Genital Mutilation

\begin{tabular}{|c|c|c|}
\hline Modes of transmission & Description & $\begin{array}{l}\text { Potential for } \mathrm{HIV} \text { transmission } \\
\text { via female genital mutilation }\end{array}$ \\
\hline \multicolumn{3}{|l|}{ Sexual intercourse } \\
\hline Vaginal-penile & $\begin{array}{l}\text { Vaginal intercourse after type } 111 \text { FGM } \\
\text { (infibulation) can be painful and causes } \\
\text { tears and bleeding, with the potential } \\
\text { danger of blood sharing between partners }\end{array}$ & yes \\
\hline Anal/Rectal-penile & $\begin{array}{l}\text { Anal intercourse may be practiced if the } \\
\text { infibulated female experiences too much } \\
\text { pain }\end{array}$ & yes \\
\hline Oral sex & $\begin{array}{l}\text { Oral sex involving vaginal and oral orifices } \\
\text { as well as penile and oral orifices }\end{array}$ & no \\
\hline Injection drug use(IDU) & $\begin{array}{l}\text { The introduction of drugs into the } \\
\text { biologic system including needle }\end{array}$ & $\begin{array}{l}\text { No, unless the mutilated female is } \\
\text { sharing also using drugs with sex } \\
\text { partner }\end{array}$ \\
\hline Exchange of blood & . & \\
\hline Tattoo practice & $\begin{array}{l}\text { Tattoo markings with same instrument } \\
\text { as part of FGM practices }\end{array}$ & yes \\
\hline$\overline{\text { IM injection }}$ & $\begin{array}{l}\text { IM injections in Africa, using the same } \\
\text { injection needle for many mutilated } \\
\text { patients in rural areas, }\end{array}$ & yes \\
\hline $\begin{array}{l}\text { Unsterile/Non surgical } \\
\text { instruments }\end{array}$ & $\begin{array}{l}\text { Using the same crude instruments to yes } \\
\text { perform FGM }\end{array}$ & \\
\hline Blood transfusion & $\begin{array}{l}\text { Blood transfusion of unscreened blood in } \\
\text { rural Africa after severe hemorrhage } \\
\text { following FGM }\end{array}$ & yes \\
\hline
\end{tabular}

A recent article, ${ }^{25}$ revealed the transmission of HIV to girls who have non-perforated hymen (virgins) and that $97 \%$ of the time, the same instrument could be used on 15-20 girls. ${ }^{26}$ This data suggest the possibility of FGM procedure as a risk variable in HIV transmission. Female Genital Mutilation may predispose women to HIV in many other ways. For example, the increased need for blood transfusions due to hemorrhage either when the procedure is performed, at childbirth, or a result of vaginal tearing during defibulation and intercourse. These tears would tend to make the squamous vaginal epithelium similar in permeability to the columnar mucosa of the rectum, thus facilitating the possibility of HIV transmission. ${ }^{27}$ In addition, many women with African Journal of Reproductive Health Vol. 11 No.1 April, 2007 type III (pharaonic) mutilation experience dyspareunia, as well as repeated tissue damage and bleeding. Difficult and painful vaginal intercourse in some of these women eventually lead to anal intercourse with heterosexual partners, further increasing the HIV risk in these women. Thus, it is plausible that HIV transmission may be enhanced by the widespread practice of FGM. ${ }^{27-30 .}$ In spite of this biologic casual plausibility, there are no epidemiologic data associating HIV transmission with FGM.

\section{Discussion}

This mini review paper has a few relevant observations. First, FGM continues to persist among populations in sub-Saharan Africa. Second, the 
non-sterile technique of this procedure has not been replaced by modern surgical technique. Third, FGM is not a standard surgical procedure in the western medical tradition. Fourth, there exists propensity or probability of HIV infection being transmitted through this practice. Fifth, epidemiologic data are needed to assess the risk of HIV infection, given exposure to FGM.

This paper which was based on original articles and other review articles on FGM has shown that in sub-Saharan Africa, countries such as Nigeria, Guinea, Ethiopia, Somalia, Djibouti and Sudan still continue to practice FGM despite a relative reduction in its prevalence. The persistence in this practice may be due to cultural beliefs, norms and traditional health beliefs, maintained among these populations. In addition, it is plausible that the practice persist due to financial gains that are associated with its practice. ${ }^{10}$

The observation of the non-sterile technique in FGM practice is supported by the fact that this procedure has not been accepted as a standard surgical procedure by modern medicine. Further, the expenses involved in sterile procedure may promote the continuous use of non-sterile technique which is less expensive and therefore affordable by the perpetrators. Regarding the acute and chronic complications associated with FGM, it is very unlikely that this practice will ever be accepted as a standard surgical procedure in the western medical tradition Also, the nonacceptability of this practice may be due to the lack of its therapeutic benefits and the life threatening outcome, including septicemia associated with more than $40 \%$ mortality rate in sub-Saharan Africa.

Human Immunodeficiency Virus transmission through FGM is plausible. First, the probability of pathogenic transfer to the blood stream increases with any non-sterile procedure. Second, bleeding or blood loss during this procedure increases exchange of blood and blood contacts which serves as one of the modes of HIV transmission. Third, blood loss during the process may compromise immune responsiveness thus increasing the probability of HIV sero-conversion. Fourth, the presence of genital lacerations augments the probability of transmission, given sexual contact with an infected individual.

The lack of epidemiologic data necessitates further hypothesis generation and testing, commencing with ecologic design, cross-sectional design and case-control studies to assess whether or not FGM increases the risk of HIV transmission. To date, there are a few reported cases, which limit any epidemiological inference on the role of FGM in HIV transmission.

Albeit the strength in this paper, there are a few limitations. It is possible that our mini- review is biased since we were not able to guarantee the inclusion of all published papers in this topic. Secondly, the lack of data on original studies, if one existed, on the association between FGM and HIV transmission significantly restricts any possible conclusion that may be drawn from this mini-review, requiring, therefore, a cautious interpretation and application of these observations. Thirdly, our paper might be biased since we were not able to examine studies published in other languages besides English.

Despite the above limitations, in summary, we have shown through this mini-review the practice of FGM, its health consequences and the limited data on the nexus between this practice and HIV transmission. In sub-Saharan Africa, while the trend of FGM does not seem to increase, the practice currently persist. The health consequences include reproductive and urinary disorders and septicemia, given the non-sterile technique involved in most of these practices performed outside the medical setting. HIV transmission involves multiple routes, one which includes blood contamination through non-sterile technique and other measures that have potentials for an association with FGM. Though case reports/series are limited in this perspective, there is plausible mechanism to implicate FGM in HIV transmission especially in populations with HIV 
preponderance such as the sub-Saharan Africa. To assess this postulate, further studies are required to answer the research question as to whether or not FGM increases the chance of HIV transmission. The knowledge of such studies will enhance our cognizance of HIV risk factors and the potential for intervention prevention in subSaharan Africa.

\section{Acknowledgement}

The preparation of this manuscript was facilitated by National Institute of Mental Health grant number RO1 MH073361-02. Also, the authors would like to thank Dr. Doriel Ward, Orsolya Garrison, MPH, Jennifer Krueger and Jonathan Brunt for reviewing the final draft of this manuscript.

\section{REFERENCES}

1. World Health Organization: Female Genital mutilation. An overview, Geneva WHO, 1998

2. Toubia N: Female circumcision as a public health issue. N Engl J Med 1994; 331: 712

3. World Health Organization: Female Genital Mutilation: Report of a WHO Technical working group, July-17-19, 1995, Geneva, WHO 1995

4. Hoskin,F P: Female genital mutilation, estimate: total number of girls and women mutilated in Africa, Lexington, MA, women international network news, 1995.

5. Toubia, N. Female genital mutilation, a call for global action, second edition, NewYork, RAINBO, 1995, 24-25.

6. WHO fact sheet no.241 :http://www.who.int/ mediacenter/factsheets/fs241/en/june2000 (accessed December 2006)

7. World Health Organization: Classification and Definitions of Female Genital cutting. Geneva, WHO. 1995

8. World Health Organization: Management of pregnancy, childbirth and the postpartum period in the presence of female genital mutilation: Report of a WHO technical consultation Geneva WHO, 2001.
9. Female Genital Mutilation and obstetric outcome: WHO collaborative prospective study in six African countries. Lancet, 2006 Jun 3; 367(9525): 1835-41.

10. Njue,C, Askew,I, Medicalization of female genital cutting among the Abuguisi in Nyanza orovince, Kenya: FRONTIERS final report, Population council. Washington 2004.

11. Sayed,GH; Abd el-Aty,M A; Fadel, KA: The practice of Female genital mutilation in upper Egypt. Int. J. Gynaecol. Obstet. 1996; 55: 285

12. Armstrong, $\mathrm{S}$; Female circumcision: fighting a cruel tradition .New scientist 1991, 129; 42.

13. Program for Appropriate Technology in Health (PATH) 1998: Improving women's sexual and reproductive health: Review of Female Genital Mutilation eradication programs in Africa, Washington: PATH, 1998.

14. Mandara, MU; Female genital mutilation in Nigeria, Int J Gynaecol Obstet 2004; 84: 291-98.

15. Shell-Dubcan B The medicalization of " female circumcision": harm reduction or promotion of a dangerous practice? Soc Sci Med 2001; 52: 1013 1028

16. Dirie M.A, Lindmark G. The risk of medical complications after female circumcision. East Afr Med. J. 1992; 62: 479-482.

17. Egwatu,V Agusa N,Complications of female circumcision in Nigerian Igbos. Br J Obstet Gynecol 1981; 88: 1090-1093

18. Odoi A, Brody SP, Elkins RE. Female genital mutilation in rural Ghana, West Africa. Intern J Gynacaecol Obstet 1997; 56: 179-180.

19. Nour, N W, Female Genital Cutting: Clinical and Cultural Guidelines, Obstetrical and Gynaecological Survey, 2004; 59(4): 272-79. (Note: tables, 2a and $2 \mathrm{~b}$, have been adapted and modified prior to inclusion in this paper.)

20. Dorkenoo, E. Combating female genital mutilation: an agenda for the next decade, World health Stat,Q ;1996; 49: 142-47

21. Larsen.U, Okonofua FE, Female circumcision and obstetric complications. Int. J. Gynaecol. Obstet. 2002 Jun; 77(3): 255-65.

22. Eke N, Nkanginieme KE, Female genital mutilation and obstetric outcome. Lancet, 2006 Jun 3; 367(9525): 1799-800. 
23. Okonofua,FE, U. Larsen, F. Oronsaye, et al. The Association between Female Genital Cutting and Correlates of Sexual and Gynaecological Morbidity in Edo State, Nigeria. Bjog-an International journal of Obstetric and Gynaecology, 2002, 109(10): 108996.

24. WHO/UNAIDS: AIDS epidemic update on world AIDS DAY, Dec 2005 (fact sheet) (accessed Dec 2005)

25. Etokidem A J. HIV/AIDS transmission through Female Genital Cutting: a case report. Int Conf AIDS 2004 Jul 11-16; 15 (abstract no. D 10677)

26. Mutenbei I B,Mwesiga MK. The impact of obsolete traditions on HIV/AIDS rapid transmission in
Africa: The case of compulsory circumcision on young girls in Tanzania. Int Conf on AIDS 1998; 12: 436(abstract 23473)

27. Hrdy DB. Cultural practices contributing to the transmission of HIV in Africa. Rev Infect Dis 1987; 9(6): 1109-1117

28. Linke U. AIDS in Africa. Science 1986; $231: 203$

29. Kun KE. Female genital mutilation: the potential for increased risk of HIV infection. Int J Gynecol Obstetr 1997; 15: 153-155.

30. Brady M. Female genital mutilation: complications and risk of HIV transmission. Aids Patient care STD 1999; 13(12): 709-16. 